WAHANA

AKUNTANSI

Jumal Ilmiah
JURNAL ILMIAH WAHANA AKUNTANSI

Vol 16 (1) 2021, 36-51

http://journal.unj/unj/index.php/wahana-akuntansi

\title{
Peran Kualitas Pelayanan dalam Kepatuhan Wajib Pajak Orang Pribadi: Sosialisasi Pajak dan Sanksi Pajak
}

\author{
*Herly Pujilestari ${ }^{1}$, Mutiara Humairo ${ }^{2}$,**Amrie Firmansyah ${ }^{3}$, Estralita Trisnawati ${ }^{4}$ \\ ${ }^{1,2,4}$ Universitas Tarumanegara, ${ }^{3}$ Politeknik Keuangan Negara STAN
}

\begin{tabular}{|c|c|}
\hline ARTICLE INFO & $A B S T R A C T$ \\
\hline $\begin{array}{l}\text { Article History: } \\
\text { Received: } 17 \text { May } 2021 \\
\text { Accepted: O6 July } 2021 \\
\text { Published: O6 July } 2021\end{array}$ & $\begin{array}{l}\text { This study aims to examine the effect of tax socialization and tax } \\
\text { sanctions on individual taxpayer compliance. In addition, this study } \\
\text { also includes service quality as a moderator in the relationship } \\
\text { between tax socialization and taxpayer compliance and the } \\
\text { relationship between tax sanctions and taxpayer compliance. This } \\
\text { study data employs primary data sourced from a survey } \\
\text { questionnaire given to respondents, namely doctors who have an } \\
\text { independent income. Based on purposive sampling, this study found } \\
66 \text { respondents who have filled out a questionnaire survey, but the } \\
\text { data that can be employed and meet the criteria of this study are } 50 \\
\text { questionnaires. This study concludes that tax socialization and tax } \\
\text { sanctions have a positive effect on taxpayer compliance. } \\
\text { Meanwhile, service quality weakens the positive effect of tax } \\
\text { socialization on tax compliance and strengthens the positive effect } \\
\text { of tax sanctions on taxpayer compliance. This research indicates } \\
\text { that the Indonesian Tax Authorities need to improve all types of } \\
\text { services to taxpayers. }\end{array}$ \\
\hline
\end{tabular}

\begin{abstract}
ABSTRAK
Penelitian ini bertujuan untuk menguji pengaruh sosialisasi pajak dan sanksi pajak terhadap kepatuhan wajib pajak orang pribadi. Selain itu, penelitian ini juga memasukkan kualitas pelayanan sebagai pemoderasi dalam hubungan antara sosialisasi pajak dan kepatuhan wajib pajak dan hubungan antara sanksi pajak dan kepatuhan wajib pajak. Data penelitian ini menggunakan data primer yang bersumber dari survei kuesioner yang diberikan kepada responden yaitu dokter yang memiliki penghasilan independen. Berdasarkan purposive sampling, penelitian ini mendapatkan 66 responden yang telah mengisi survei kuesioner, namun data yang dapat digunakan dan memenuhi kriteria penelitian ini sejumlah 50 kuisioner. Penelitian ini menyimpulkan bahwa sosialisasi pajak dan sanksi pajak berpengaruh positif terhadap kepatuhan wajib pajak. Sementara itu, kualitas pelayanan memperlemah pengaruh positif sosialisasi pajak terhadap kepatuhan pajak dan memperkuat pengaruh positif sanksi pajak terhadap kepatuhan wajib pajak. Penelitian ini mengindikasikan bahwa Otoritas Perpajakan di Indonesia perlu meningkatkan semua jenis pelayanan kepada wajib pajak.
\end{abstract}

How to Cite:

Pujilestasri, Herly, Mutiara Humairo, Amrie Firmansyah, dan Estralita Trisnawati. (2021). Peran Kualitas Pelayanan dalam Kepatuhan Wajib Pajak Orang Pribadi: Sosialisasi Pajak dan Sanksi Pajak. Jurnal Ilmiah Wahana Akuntansi, 16(1), 36-51. https://doi.org/10.21009/wahana.16.013 


\section{PENDAHULUAN}

Pajak merupakan sumber penerimaan pemerintah untuk membiayai keperluan negara (Nurisdiyanto, 2019). Penerimaan pajak terus menunjukkan angka peningkatan yang cukup baik pada setiap tahunnya. Pada Tabel 1 di bawah menunjukkan naik turunnya kontribusi pajak pada anggaran pendapatan dan belanja negara (APBN).

\section{Tabel 1}

Kontribusi Perpajakan pada APBN (\%)

\begin{tabular}{lrrrrrr}
\hline \multicolumn{1}{c}{ Tahun } & $\mathbf{2 0 1 6}$ & $\mathbf{2 0 1 7}$ & $\mathbf{2 0 1 8}$ & $\mathbf{2 0 1 9}$ & $\mathbf{2 0 2 0}$ & $\mathbf{2 0 2 1}$ \\
\hline Perpajakan & 82,60 & 84,80 & 85,40 & 82,47 & 82,62 & 82,82 \\
PNBP & 16,80 & 15,00 & 14,50 & 17,46 & 17,30 & 17,10 \\
Hibah & 0,60 & 0,20 & 0,10 & 0,06 & 0,08 & 0,08 \\
\hline
\end{tabular}

Sumber: Kementerian Keuangan, Tahun 2021

\section{Kementerian Keuangan (Kemenkeu)}

mencatat defisit anggaran pendapatan dan belanja negara (APBN) sepanjang 2020 sebesar Rp956,3 Triliun (https://nasional.kontan.co.id). Menteri Keuangan Sri Mulyani mengatakan penerimaan negara mengalami penurunan akibat realisasi penerimaan pajak yang kontraksi hingga 19,7\% (Imam, 2021). Adanya pandemi virus corona mengakibatkan perlambatan perekonomian. Kondisi seperti ini menekan pemerintah pajak untuk tetap menggunakan instrumen perpajakan sebagai salah satu instrumen untuk mendukung pemulihan ekonomi nasional dengan memberikan insentif yang selektif dan terukur (Fitriani, 2021). Insentif tersebut mendorong untuk wajib pajak tidak merasa terbebani dalam memenuhi kewajiban perpajakannya.

Tingkat kepatuhan wajib pajak dapat dilihat dari tingkat partisipasi wajib pajak dalam melaporkan SPT Tahunan. Meningkatkan kepatuhan wajib pajak merupakan salah satu upaya negara untuk meningkatkan pendapatan negara (Surya, 2019).

Gambar 1 di bawah ini merupakan rasio kepatuhan WP Badan dan WP Pribadi Non Karyawan untuk tahun 2015-2020.

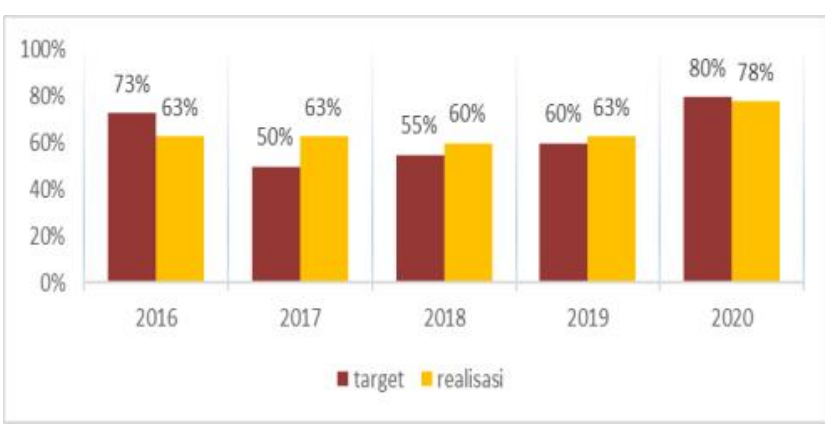

\section{Gambar 1}

\section{Rasio Kepatuhan WP Badan dan WP Pribadi Non Karyawan 2015-2020}

Sumber: Laporan Kinerja DJP 2015-2020

Berdasarkan Laporan Kinerja Direktorat Jenderal Pajak yang diperoleh dari lima tahun terakhir menunjukkan tingkat kepatuhan wajib pajak tahun 2015 sampai 2020 (www.pajak.go.id). Pada tahun 2020 menunjukkan tingkat kepatuhan wajib pajak tidak mencapai target yang diharapkan (https:// www.pajak.go.id). Target yang diharapkan oleh pemerintah pajak adalah sebesar 80\% namun tingkat pencapaian hanya $78 \%$. Angka pencapaian ini menunjukkan penurunan tingkat kepatuhan wajib pajak badan dan wajib pajak non karyawan. Salah satu faktor penurunan penerimaan negara ialah pandemi. Di masa pandemi semua organisasi harus terus menekan biaya untuk tetap bertahan. Penekanan biaya ini mempengaruhi pendapatan individu yang merupakan wajib pajak orang pribadi.

Penerimaan pajak pemerintah selain 
bersumber dari wajib pajak badan, dapat bersumber dari wajib pajak orang pribadi. Keberhasilan wajib pajak orang pribadi tergantung dari kepatuhan wajib pajak tersebut dalam memenuhi kepatuhan perpajakannya kepada pemerintah. Kepatuhan pajak erat kaitannya dengan kesediaan wajib pajak untuk mematuhi ketentuan perpajakan (Andreoni et al., 1998). Rogers-Glabush (2009) menyatakan bahwa kepatuhan pajak merupakan tindakan prosedural dan administratif yang diperlukan oleh wajib pajak untuk melaksanakan kewajiban perpajakan. Kepatuhan pajak dari wajib orang pribadi dapat dipengaruh dari hal-hal positif yang mereka persepsikan. Apabila terdapat dukungan dari pihak-pihak di sekitar wajib pajak tersebut, dan adanya persepsi kemudahan dalam berperilaku, maka niat wajib pajak orang pribadi tersebut akan tinggi (Ajzen, 2010). Kondisi ideal dan kondisi yang sebenarnya terkait dengan kepatuhan wajib pajak orang pribadi mungkin terdapat perbedaan, sehingga faktor-faktor yang mempengaruhi kepatuhan wajib pajak orang pribadi perlu diinvestigasi lebih lanjut.

Arham \& Firmansyah (2021) telah menginvestigasi faktor-faktor yang mempengaruhi kepatuhan wajib pajak orang pribadi pada sektor usaha kecil dan menengah. Berdasarkan investigasi tersebut terdapat tiga faktor yang biasanya digunakan yaitu pengetahuan perpajakan sebagaimana Putra \& Firmansyah (2018), Syaputra (2019), Pangesti \& Yushita (2019), Nifanngeljau \& Sularsih (2020), Perdana \& Dwirandra (2020), Setiyawan et al. (2020), Suardana \& Gayatri (2020), Wardani \& Kartikasari (2020), Putra (2020), Zulma (2020).
Faktor lainnya yaitu sanksi perpajakan sebagaimana Putri \& Nurhasanah (2019), Zelmiyanti \& Suwardi (2019), Nifanngeljau \& Sularsih (2020), Perdana \& Dwirandra (2020), Putra (2020), Zulma (2020). Selanjutnya, kesadaran wajib pajak digunakan dalam pengujian kepatuhan wajib pajak orang pribadi sebagaimana Setiyawan et al. (2020), Nifanngeljau \& Sularsih (2020), Perdana \& Dwirandra (2020). Pengujian kepatuhan pajak lainnya menggunakan keadilan pajak (Pradana \& Firmansyah, 2020).

Undang- undang perpajakan di Indonesia selalu mengalami perubahan sesuai dengan perubahan ekonomi. Terlebih, dengan adanya pandemi, DJP banyak menerbitkan aturan turunan perpajakan yang baru untuk menyesuaikan dengan keadaan perekonomian yang terjadi akibat pandemi. Dengan adanya perubahan tersebut wajib pajak dituntut agar selalu mengetahui perubahan tersebut agar tetap taat pajak. Namun, pihak DJP juga harus gencar melakukan sosialisasi terhadap peraturan perpajakan yang terbaru agar dapat menuntun wajib pajak untuk selalu mengetahui pembaharuan tentang perpajakan. Pernyataan ini selaras dengan yang diungkapkan oleh Sukesi \& Yunaidah (2020) bahwa sosialisasi memiliki pengaruh positif terhadap kepatuhan wajib pajak. Berbeda dengan hasil penelitian yang dilakukan oleh Sesarista (2020) dalam penelitiannya mengungkapkan bahwa sosialisasi pajak tidak berpengaruh terhadap kepatuhan pajak. Oleh karena itu, pengujian sosialisasi pajak terhadap kepatuhan pajak perlu dilakukan investigasi lebih lanjut. 
Selain melakukan sosialisasi pemerintah pajak juga menerapkan sanksi pajak bagi wajib pajak yang tidak mengikuti aturan pajak. Hal itu bertujuan untuk memberikan dorongan kepada wajib pajak agar selalu patuh atas perpajakannya. Berdasarkan UU Ketentuan Umum dan Tata Cara Perpajakan (UU KUP), terdapat 2 jenis sanksi perpajakan yaitu sanksi administrasi dan sanksi pidana. Sanksi administrasi perpajakan meliputi bunga, denda dan kenaikan, sedangkan sanksi pidana perpajakan berupa kurungan penjara. Beberapa penelitian tentang pengaruh sanksi pajak terhadap kepatuhan pajak telah dilakukan oleh Firnanda (2018), Dewi \& Jati (2018), dan Pratama \& Mulyani (2019). Penelitian Firnanda (2018) menunjukkan bahwa sanksi pajak berpengaruh negatif terhadap kepatuhan pajak. Sementara itu, Dewi \& Jati (2018), serta Pratama \& Mulyani (2019) menemukan bahwa sanksi pajak berpengaruh positif terhadap kepatuhan pajak. Adanya inkonsistensi hasil pengujian sebelumnya, pengujian sanksi pajak terhadap kepatuhan pajak perlu untuk dilakukan.

Penelitian ini bertujuan untuk menguji kepatuhan pajak dan sanksi pajak terhadap kepatuhan pajak. Adanya perbedaan dalam pengujian hasil penelitian sebelumnya mengakibatkan pengujian kembali kepatuhan pajak dan sanksi pajak untuk dilakukan. Penelitian ini juga memasukkan kualitas pelayanan sebagai pemoderasi. Penelitian ini dilakukan untuk menunjukkan hasil yang berbeda dengan penelitian Savitri \& Musfialdy (2016) yang menggunakan kualitas pelayanan sebagai variabel mediasi dan menggunakan sampel wajib pajak kendaraan bermotor. Upaya peningkatan kepatuhan wajib pajak yang dilakukan oleh pemerintah pajak tidak berhenti dengan sosialisasi dan sanksi (Azyus et al., 2017). Namun, pemerintah pajak juga harus meningkatkan layanan pajak bagi wajib pajak guna mempertahankan wajib pajak untuk tetap patuh terhadap kewajiban perpajakannya. Wajib pajak yang merasa puas dengan kualitas pelayanan pajak diharapkan mampu melengkapi perilakunya dalam melakukan pembayaran pajak. Namun, berbeda dengan situasi yang ada sekarang, pengalaman yang terjadi di lapangan sering terjadi error pada situs DJP online (situs pajak). Indraini (2021) menyatakan adanya kendala saat pelaporan, seperti tidak mendapat kode verifikasi dan situs error, memungkinkan wajib pajak telat bayar atau lapor. Hal ini terjadi pada saat yang kurang tepat seperti pada saat deadline bayar dan deadline lapor. Pada saat seperti itu tidak semua helpdesk dapat fast response dan memberikan solusi pada kendala tersebut. Oleh karena itu, menunjukkan tingkat pelayanan pajak yang rendah penurunan tingkat kepatuhan wajib pajak tersebut dan dapat merujuk ke pengenaan sanksi terhadap wajib pajak.

Penelitian ini menggunakan responden wajib pajak penghasilan orang pribadi non karyawan dengan profesi dokter. Syambudi (2020) menyatakan bahwa banyak tenaga medis yang belum terpenuhi hak atas gajinya, bahkan ada beberapa dokter yang menerima gajinya kurang dari biasanya. Kondisi tersebut dapat mempengaruhi jumlah pembayaran pajak wajib pajak dengan profesi independen sebagai dokter. 


\section{TINJAUAN TEORI}

\section{Teori Perilaku Terencana (Theory Of Planned} Behavior)

Teori perilaku terencana merupakan teori yang berpandangan dari sisi psikologi individu pada saat ingin melakukan suatu tindakan (Kan \& Fabrigar, 2017). Sebelum melakukan suatu tindakan atau perilaku individu akan memikirkan dan mempertimbangkan akibat dari hal tersebut dan memutuskan untuk melakukan tindakan tersebut atau tidak (Ajzen, 2010). Beberapa faktor terkait dengan teori perilaku terencana adalah keyakinan perilaku, keyakinan normatif dan keyakinan kendali. Keyakinan perilaku menghasilkan sikap terhadap perilaku positif atau negatif, keyakinan normatif menghasilkan tekanan sosial yang dipersepsikan dan menimbulkan kontrol keperilakuan yang dipersepsikan, yang akan mempengaruhi niat dan perilaku seseorang atau individu (Afdalia et al., 2014).

Dalam keadaan yang sulit semua individu akan mengutamakan kebutuhan primernya terlebih dahulu. Banyak pekerja dari berbagai bidang tidak mendapat penghasilan seperti harihari sebelumnya bahkan kehilangan pekerjaannya. Di salah satu rumah sakit di Indonesia, banyak tenaga medis termasuk dokter yang belum dibayarkan gajinya dan mendapatkan gaji lebih kecil dari biasanya (Syambudi 2020). Kondisi ini dapat mendorong niat untuk tidak peduli tentang perpajakan sehingga dapat dikategorikan sebagai tidak patuh. Namun berbeda halnya jika individu tersebut mendapat dorongan untuk patuh seperti pemberitahuan dari pegawai kantor pelayanan pajak.
Yasa (2017) menyatakan bahwa niat merupakan dasar seorang wajib pajak untuk berperilaku patuh. Selain itu kepatuhan seorang wajib pajak juga didukung oleh norma subjektif dan pengendali perilaku kepatuhan. Hal lainnya adalah seberapa kuat keberadaan hal-hal yang dapat mendukung dan menghambat perilaku seorang wajib pajak. Niat untuk patuh pada perpajakan merupakan pilihan setiap individu. Pemerintah pajak telah berupaya menuntun wajib pajak seperti menerapkan penalti pajak dan melakukan sosialisasi pajak ketika terdapat adanya perubahan peraturan dengan tujuan wajib pajak mengikuti ketentuan tersebut.

\section{Pengembangan Hipotesis}

Sosialisasi pajak merupakan otoritas pajak untuk memberikan informasi, pengertian, dan pembinaan kepada masyarakat khususnya wajib pajak mengenai perpajakan dan perundang-undangannya (Savitri \& Musfialdy, 2016). Adanya sosialisasi diharapkan wajib pajak tetap dapat memahami ketentuan yang berlaku, sehingga wajib pajak dapat melaksanakan kewajiban perpajakannya dengan baik. Sosialisasi pajak erat kaitannya dengan kepercayaan perilaku. Apabila pemahaman wajib pajak terhadap ketentuan perpajakan akibat adanya sosialisasi perpajakan yang baik, maka wajib pajak diharapkan akan memiliki keyakinan mengenai pentingnya membayar pajak untuk membantu pembangunan negara (Purba, 2016).

Sukesi \& Yunaidah (2020) dan Savitri \& Musfialdy (2016) mengungkapkan bahwa sosialisasi memiliki pengaruh positif terhadap 
kepatuhan wajib pajak. Sosialisasi merupakan upaya untuk memperkenalkan aturan-aturan yang berlaku dengan perpajakan. Selain itu, sosialisasi juga merupakan media bagi otoritas perpajakan untuk mendorong masyarakat berperan aktif dalam membangun negara melalui kewajiban membayar pajak. Bagi seorang dokter yang memiliki penghasilan independen merupakan wajib pajak orang pribadi menganggap bahwa sosialisasi pajak merupakan alasan logis dalam memenuhi kewajiban perpajakannya kepada negara. Oleh karena itu, hipotesis pertama dalam penelitian ini adalah:

$\mathrm{H}_{1}$ : Sosialisasi pajak berpengaruh positif terhadap kepatuhan pajak.

Sanksi pajak merupakan hukuman negatif bagi pihak yang melanggar dengan membayar sejumlah uang (Savitri \& Musfialdy, 2016). Sanksi pajak dapat digunakan oleh pemerintah untuk menertibkan administrasi perpajakan supaya wajib pajak patuh terhadap peraturan perpajakan. Terkait dengan teori perilaku terencana, pajak dapat dikaitkan dengan keyakinan kendali di mana sanksi pajak yang tegas akan membatasi wajib pajak yang tidak patuh (Dewi \& Jati, 2018). Adanya sanksi yang diberikan oleh otoritas perpajakan selaku wakil pemerintah mengakibatkan wajib pajak tidak memiliki pilihan selain tidak patuh dalam memenuhi kewajiban perpajakannya.

Dewi \& Jati (2018) dan Pratama \& Mulyani (2019) menemukan bahwa sanksi pajak berpengaruh positif terhadap kepatuhan wajib pajak. Sanksi perpajakan diberikan sebagai konsekuensi dari sikap wajib pajak yang tidak melaporkan kewajiban perpajakannya kepada pemerintah. Dokter selaku wajib pajak orang pribadi yang memiliki penghasilan independen cenderung untuk taat memenuhi kewajiban perpajakannya. Profesi dokter seminimal mungkin menghindari sanksi perpajakan di kemudian hari karena sanksi tersebut dapat berakibat terkait dengan aktivitas profesinya di masa depan. Dengan demikian, hipotesis kedua dalam penelitian ini adalah:

\section{$\mathrm{H}_{2}$ : Sanksi pajak berpengaruh positif terhadap} kepatuhan pajak.

Sistem perpajakan di Indonesia menganut sistem self-assessment, yang berarti sistem pemungutan pajaknya memberi kepercayaan kepada wajib pajak untuk menghitung, membayar, dan melaporkan sendiri jumlah pajak yang terutang. Pengetahuan perpajakan menjadi salah satu isu penting dalam sistem self -assessment karena dalam sistem tersebut para wajib pajak mau tidak mau harus mengetahui pengetahuan mengenai perpajakan agar dapat memenuhi kewajiban perpajakan sendiri sesuai peraturan perundang-undangan (Palil, 2010). Oleh karena itu, pengetahuan perpajakan memiliki peranan penting dalam meningkatkan kepatuhan pajak (Oladipupo \& Obazee, 2016). Salah satu langkah yang harus dilakukan otoritas pajak di Indonesia dalam meningkatkan pengetahuan pajak adalah melakukan sosialisasi perpajakan. Eriksen \& Fallan menunjukkan bahwa cara yang paling ampuh dalam mencegah penghindaran pajak adalah dengan memberikan lebih banyak pengetahuan pajak kepada segmen masyarakat yang lebih luas untuk memperbaiki etika pajak dan konsepsi masyarakat tentang kewajaran sistem 
pajak. Pelayanan pajak berkaitan dengan keyakinan normatif dalam konteks teori perilaku terencana. Kondisi ini dapat dikaitkan dengan harapan yang diperkirakan seseorang atau lebih untuk memotivasi individu dan menerima perilaku tertentu agar mereka dipatuhi. Kepatuhan wajib pajak dalam melaksanakan kewajiban pajak akan meningkat apabila pelayanan yang didapat dari petugas pajak dapat memberikan rasa puas (Purba, 2016).

Mahaputri \& Noviari (2016), Rusmayani \& Supadmi (2017) dan Dharma et al., (2014) membuktikan bahwa kualitas pelayanan dapat meningkatkan kepatuhan wajib pajak. Kualitas pelayanan memiliki peran dalam mendorong wajib pajak orang pribadi khususnya dokter yang memiliki penghasilan independen semakin merasa penting untuk memenuhi kewajiban perpajakannya. Kualitas pelayanan yang dicerminkan oleh pegawai otoritas pajak di Indonesia menunjukkan kepada dokter selaku wajib pajak bahwa pengelolaan pajak dilakukan secara baik dan profesional. Dengan demikian, hipotesis ketiga dalam penelitian ini adalah:

$\mathrm{H}_{3}$ : Kualitas pelayanan memperkuat pengaruh positif sosialisasi pajak terhadap ketaatan pajak.

Salah satu faktor yang menimbulkan niat individu untuk berperilaku niat berperilaku dalam Teori Perilaku Terencana adalah keyakinan kendali. Keyakinan tersebut menjelaskan mengenai keberadaan hal-hal yang mendukung atau menghambat perilaku yang akan ditampilkan (Putra \& Firmansyah, 2018). Murphy (2008) menemukan bahwa strategi sanksi yang diberikan kepada individu dapat meningkatkan kepatuhan pajak. Selain itu, Ortega \& Sanguinetti (2013) menyatakan bahwa komunikasi yang dilakukan dengan tujuan untuk penekanan kepada individu dapat mengakibatkan individu tersebut taat terhadap kewajiban perpajakannya. Di sisi lain, otoritas Pajak di Indonesia menganggap bahwa pelayanan yang baik dapat mendorong wajib pajak menjadi lebih taat atas kewajiban perpajakannya. Kondisi ini dibuktikan oleh Mahdani \& Ismatullah (2021), Syafira \& Nasution (2021), Pebrina \& Hidayatulloh (2020) yang menemukan bahwa kualitas pelayanan yang baik dapat mendorong peningkatan kepatuhan pajak.

Beberapa strategi yang dilakukan oleh otoritas pajak di Indonesia untuk meningkatkan kepatuhan pajak adalah dengan memberikan pelayanan yang baik kepada wajib pajak dan memberikan sanksi pajak bagi wajib pajak yang tidak memenuhi kewajiban perpajakannya. Kepatuhan pajak dari wajib pajak diharapkan dapat meningkatkan penerimaan pemerintah dari sektor perpajakan. Di sisi lain, wajib pajak juga perlu mengetahui alasan bahwa wajib pajak tersebut harus memenuhi kewajiban pajaknya. Dari sudut pandang wajib pajak orang pribadi dengan penghasilan independen, dokter lebih menghindari adanya sanksi yang diberikan oleh otoritas perpajakan. Selain itu, dokter memiliki pengetahuan perpajakan yang memadai berdasarkan pelayanan yang diberikan oleh kantor pelayanan pajak baik secara langsung ataupun tidak langsung. Oleh karena itu, hipotesis keempat dalam penelitian ini adalah: 


\author{
$\mathrm{H}_{4}$ : Kualitas pelayanan memperkuat \\ pengaruh positif sanksi pajak terhadap \\ ketaatan pajak.
}

\section{METODOLOGI PENELITIAN}

Penelitian ini menggunakan metode kuantitatif. Teknik pemilihan sampel menggunakan purposive sampling yaitu individu berprofesi dokter yang masih aktif bekerja yang memiliki penghasilan independen di area Jabodetabek. Periode pengambilan sampel dilakukan dalam periode 16-25 Maret 2021. Kuesioner didistribusikan kepada responden dengan cara langsung melalui aplikasi google form berupa formulir yang diisi narasumber secara online.

Dari penyebaran kuesioner secara online didapatkan 66 responden yang mengisi kuesioner. Terdapat 16 dari 66 responden yang bukan berprofesi sebagai dokter, sehingga data yang dapat digunakan dan memenuhi kriteria sebanyak 50 kuesioner.

Variabel endogen dalam penelitian ini kepatuhan pajak, sedangkan variabel eksogen adalah sosialisasi pajak dan sanksi pajak. Selain itu, dalam penelitian ini juga memasukkan variabel moderasi yaitu kualitas pelayanan. Adapun indikator yang digunakan untuk masingmasing variabel disajikan pada Tabel 2.

Metode analisis data yang digunakan dalam penelitian ini adalah Analisis Jalur (Path Analysis) untuk menganalisis pengaruh variabel eksogen yaitu sosialisasi pajak dan sanksi pajak terhadap variabel endogen yaitu kepatuhan wajib pajak, serta variabel moderasi yaitu kualitas pelayanan. Data penelitian dianalisis dengan melakukan uji validitas dan uji reliabilitas dengan bantuan software Partial Least Square (PLS). Penggunaan PLS untuk mengolah data dengan jumlah sampel yang relatif sedikit, yaitu berjumlah 50 .

Tabel 2

Operasional Variabel Penelitian

\begin{tabular}{|c|c|c|c|}
\hline Variabel & Definisi & Indikator & Skala \\
\hline $\begin{array}{l}\text { Sosialisasi } \\
\text { Pajak }\left(\mathrm{X}_{1}\right)\end{array}$ & $\begin{array}{l}\text { Upaya yang } \\
\text { dilakukan Dirjen } \\
\text { Pajak untuk } \\
\text { memberikan } \\
\text { informasi, } \\
\text { pengertian, dan } \\
\text { pembinaan kepada } \\
\text { masyarakat } \\
\text { khususnya wajib } \\
\text { pajak mengenai } \\
\text { perpajakan dan } \\
\text { perundang- } \\
\text { undangannya. }\end{array}$ & 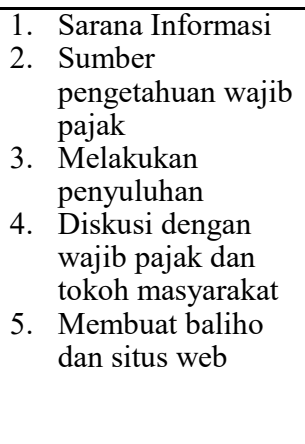 & $\begin{array}{l}\text { Likert } \\
1-5\end{array}$ \\
\hline $\begin{array}{l}\text { Sanksi } \\
\text { Pajak }\left(X_{2}\right)\end{array}$ & $\begin{array}{l}\text { Alat yang } \\
\text { digunakan oleh } \\
\text { pemerintah untuk } \\
\text { menertibkan } \\
\text { administrasi } \\
\text { perpajakan supaya } \\
\text { wajib pajak patuh } \\
\text { terhadap peraturan } \\
\text { perpajakan. }\end{array}$ & $\begin{array}{l}\text { 1. Sanksi yang ketat } \\
\text { 2. Sanksi akibat } \\
\text { pelanggaran } \\
\text { 3. Sanksi untuk } \\
\text { pendisiplinan } \\
\text { 4. Sanksi yang } \\
\text { sepadan }\end{array}$ & $\begin{array}{l}\text { Likert } \\
1-5\end{array}$ \\
\hline $\begin{array}{l}\text { Kepatuhan } \\
\text { Pajak (Y) }\end{array}$ & $\begin{array}{l}\text { Kesediaan wajib } \\
\text { pajak untuk } \\
\text { memenuhi } \\
\text { kewajiban } \\
\text { perpajakannya } \\
\text { sesuai dengan } \\
\text { aturan yang } \\
\text { berlaku tanpa } \\
\text { perlu diadakannya } \\
\text { pemeriksaan, } \\
\text { penyidikan, } \\
\text { peringatan atau } \\
\text { ancaman, dalam } \\
\text { penerapan sanksi } \\
\text { baik hukum } \\
\text { maupun } \\
\text { administrasi. }\end{array}$ & $\begin{array}{l}\text { 1. Berusaha paham } \\
\text { pajak } \\
\text { 2. Lapor tepat waktu } \\
\text { 3. Bayar tepat waktu } \\
\text { 4. Menyampaikan } \\
\text { yang sebenarnya }\end{array}$ & $\begin{array}{l}\text { Likert } \\
1-5\end{array}$ \\
\hline $\begin{array}{l}\text { Kualitas } \\
\text { Pelayanan } \\
\text { (Z) }\end{array}$ & $\begin{array}{l}\text { Kualitas pelayanan } \\
\text { pajak untuk } \\
\text { membantu WP } \\
\text { memahami hak } \\
\text { dan kewajiban } \\
\text { sebagai wajib } \\
\text { pajak } \\
\text { Pertimbangan } \\
\text { keberatan wajib } \\
\text { pajak terhadap } \\
\text { pajak yang } \\
\text { dikenakan. }\end{array}$ & $\begin{array}{l}\text { 1. Layanan pajak } \\
\text { yang baik } \\
\text { 2. Perlakukan yang } \\
\text { adil } \\
\text { 3. Membantu wajib } \\
\text { pajak } \\
\text { 4. Mempertimbankan } \\
\text { masukan wajib } \\
\text { pajak }\end{array}$ & $\begin{array}{l}\text { Likert } \\
1-5\end{array}$ \\
\hline
\end{tabular}

Sumber: Savitri \& Musfialdy (2016) dan Samudra et al., (2020) 
HASIL DAN PEMBAHASAN

Statistik deskriptif penelitian ini disajikan pada Tabel 3 di bawah ini.

\section{Tabel 3}

\section{Statistik Deskriptif}

\begin{tabular}{lrrrrr}
\hline \multicolumn{1}{c}{ Variabel } & N & Min. & Max. & Mean & $\begin{array}{c}\text { Std. } \\
\text { Deviation }\end{array}$ \\
\hline Sosialisasi Pajak & 50 & 1,00 & 5,00 & 0,849 & 3,744 \\
Sanksi Pajak & 50 & 1,00 & 5,00 & 0,843 & 3,895 \\
Kepatuhan Pajak & 50 & 2,00 & 5,00 & 0,678 & 3,626 \\
Kualitas Pelayanan & 50 & 1,00 & 5,00 & 0,946 & 3,363 \\
\hline
\end{tabular}

Sumber: Data diolah oleh peneliti, Tahun 2021

Selanjutnya, untuk menguji hubungan antar variabel, harus dilakukan uji validitas dan uji reliabilitas. Untuk uji validitas, factor loading dari hasil output Smart PLS dapat dinyatakan valid apabila factor loading lebih besar dari 0,5. Tabel 4 di bawah ini merupakan ringkasan output factor loading untuk indikator per masingmasing variabel yang mencerminkan hasil uji validitas.

Tabel 4

Ringkasan Hasil Uji Validitas

\begin{tabular}{lrrrr}
\hline Item & $\begin{array}{c}\text { Tax } \\
\text { Compiance }\end{array}$ & $\begin{array}{c}\text { Tax } \\
\text { Pinalties }\end{array}$ & $\begin{array}{c}\text { Tax } \\
\text { Socialization }\end{array}$ & $\begin{array}{c}\text { Service } \\
\text { Quality }\end{array}$ \\
\hline Y.1 & 0.887 & & & \\
Y.2 & 0.885 & & & \\
Y.3 & 0.820 & & & \\
Y.4 & 0.876 & & & \\
X1.1 & & 0.680 & & \\
X1.2 & & 0.754 & & \\
X1.3 & & 0.807 & & \\
X1.4 & & 0.800 & & \\
X1.5 & & 0.761 & & \\
X2.1 & & & 0.774 & \\
X2.2 & & & 0.592 & \\
X2.3 & & & 0.888 & \\
X2.4 & & & 0.847 & \\
Z.1 & & & & 0.836 \\
Z.2 & & & & 0.861 \\
Z.3 & & & & \\
Z.4 & & & & \\
\hline
\end{tabular}

Sumber: Data diolah oleh peneliti, Tahun 2021
Berdasarkan hasil uji validitas di atas, semua nilai indikator factor loading untuk seluruh indikator di atas $>0,5$ sehingga semua indikator variabel sosialisasi pajak, sanksi pajak, kepatuhan pajak, dan kualitas pelayanan dinyatakan valid (Hair et al., 2013).

Hasil uji reliabilitas atas variabel yang digunakan dalam penelitian ini disajikan pada Tabel 5.

\section{Tabel 5}

Ringkasan Hasil Uji Reliabilitas

\begin{tabular}{lrr}
\hline \multicolumn{1}{c}{ Variabel } & $\begin{array}{c}\text { Composite } \\
\text { Reliability }\end{array}$ & $\begin{array}{c}\text { Cronbach's } \\
\text { Alpha }\end{array}$ \\
\hline Sosialisasi Pajak & 0,873 & 0,844 \\
Sanksi Pajak & 0,862 & 0,788 \\
Kepatuhan Pajak & 0,924 & 0,891 \\
Kualitas & 0,930 & 0,904 \\
Pelayanan & \\
\hline
\end{tabular}

Sumber: Data diolah oleh peneliti, Tahun 2021

Semua variabel dalam penelitian ini memiliki nilai Cronbach Alpha $>0,6$, sehingga semua variabel digunakan dalam penelitian ini dinyatakan reliabel (Sujarweni, 2015).

Selanjutnya, ringkasan hasil uji hipotesis dalam penelitian ini disajikan pada Tabel 6 di bawah ini.

Tabel 6

\section{Ringkasan Hasil Uji Hipotesis}

\begin{tabular}{|c|c|c|c|c|}
\hline $\begin{array}{c}\text { Hubungan Antar } \\
\text { Variabel }\end{array}$ & $\begin{array}{l}\text { Original } \\
\text { Sampel }\end{array}$ & $\begin{array}{l}\text { Sampel } \\
\text { Mean }\end{array}$ & $\begin{array}{l}\text { t- } \\
\text { stat. }\end{array}$ & $\begin{array}{c}P \text { - } \\
\text { Value }\end{array}$ \\
\hline $\begin{array}{l}\text { Sosialisasi Pajak -> } \\
\text { Kepatuhan Pajak }\end{array}$ & 0,329 & 0,331 & 4,841 & 0,000 \\
\hline $\begin{array}{l}\text { Sanksi Pajak-> } \\
\text { Kepatuhan Pajak }\end{array}$ & 0,253 & 0,258 & 3,435 & 0,001 \\
\hline $\begin{array}{l}\text { Sosialisasi Pajak } \\
\text { *Kualitas Pelayanan - } \\
>\text { Kepatuhan Pajak }\end{array}$ & $-0,269$ & $-0,270$ & 3,530 & 0,000 \\
\hline $\begin{array}{l}\text { Sanksi Pajak } \\
\text { *Kualitas Pelayanan - } \\
>\text { Kepatuhan Pajak }\end{array}$ & 0,266 & 0,258 & 3,265 & 0,001 \\
\hline
\end{tabular}

Pengaruh Sosialisasi Pajak Terhadap Kepatuhan Pajak 
Hasil pengujian hipotesis menunjukkan bahwa sosialisasi pajak berpengaruh positif terhadap kepatuhan pajak. Hasil pengujian ini sejalan dengan Sukesi \& Yunaidah (2020) dan Savitri \& Musfialdy (2016). Sosialisasi pajak yang baik dapat mengarahkan kepatuhan wajib pajak orang pribadi karena informasi positif yang diberikan pada saat sosialisasi memberikan motivasi kepada wajib pajak untuk menjadi taat pajak. Hasil penelitian ini juga menunjukkan bahwa sosialisasi pajak dapat meningkatkan pengetahuan pajak dari wajib pajak khususnya dokter yang memiliki penghasilan independen. Kondisi ini sejalan dengan pernyataan Oladipupo \& Obazee (2016).

Terkait dengan keyakinan perilaku, profesi dokter sebagai responden penelitian, merupakan orang-orang dengan tingkat pendidikan yang tinggi yang dengan mudah untuk menerima dan memahami informasi-informasi baru (informasi perpajakan), dan melaksanakannya sesuai dengan aturan yang berlaku. Wajib pajak dokter memiliki keyakinan dapat memberikan kontribusi dalam pembangunan negara melalui pembayaran pajak kepada pemerintah. Selain itu, dokter sebagai wajib pajak orang pribadi merasa bahwa sosialisasi pajak yang dilakukan oleh pegawai otoritas perpajakan di Indonesia memberikan keyakinan terkait dengan fungsi pajak untuk meningkatkan kepentingan umum dan menyejahterakan masyarakat (Firmansyah, 2020).

\section{Pengaruh Sanksi Pajak Terhadap Kepatuhan Pajak}

Hasil pengujian hipotesis menunjukkan bahwa sanksi pajak berpengaruh positif terhadap kepatuhan pajak. Hasil pengujian ini sejalan dengan Dewi \& Jati (2018) dan Pratama \& Mulyani (2019). Hasil pengujian ini juga sejalan dengan pernyataan Murphy (2008) bahwa strategi otoritas pajak dalam pemberian sanksi individu dapat meningkatkan kepatuhan pajak. Salah satu dalam Teori Perilaku Terencana adalah keyakinan kendali yang mengakibatkan bahwa individu dapat berperilaku karena adanya tekanan tertentu. Selain itu, komunikasi yang dilakukan dengan tujuan untuk menekan individu dapat mengakibatkan individu tersebut taat terhadap kewajiban perpajakannya (Ortega \& Sanguinetti, 2013).

Seorang dokter yang memiliki profesi independen menanggap bahwa sanksi pajak yang tegas akan membatasi wajib pajak untuk tidak patuh terhadap kewajibannya kepada pemerintah. Seorang dokter sebagai wajib pajak orang pribadi cenderung lebih kritis untuk menghindari sanksi perpajakan terkait. Sanksi dianggap erat kaitannya dengan ketidakpatuhan pajak kepada pemerintah. Sanksi pajak bagi dokter dapat mengakibatkan permasalahan di masa mendatang baik terkait dengan profesi pekerjaannya. Dokter sebagai wajib pajak orang pribadi menganggap bahwa apabila mereka dikenakan sanksi terkait dengan ketidakpatuhan pajak kepada pemerintah dapat berakibat merugikan dalam aktivitas profesinya maupun pendapatan yang mereka peroleh. Oleh karena itu, dokter akan lebih cenderung menghindari sanksi dan berhati-hati dalam menjalankan kewajiban perpajakannya. 


\section{Pengaruh Moderasi Kualitas Pelayanan} Terhadap Pengaruh Sosialisasi Pajak Terhadap Kepatuhan Pajak

Hasil pengujian menunjukkan bahwa kualitas pelayanan memperlemah pengaruh positif sosialisasi pajak terhadap kepatuhan pajak. Untuk mencapai sosialisasi pajak yang efektif, sosialisasi perlu dilakukan secara berkala dan berkelanjutan, yang dilakukan oleh petugas pajak yang kompeten dan komunikatif (Hazmi et al., 2020). Pelayanan pajak dirasakan oleh wajib pajak dokter dengan profesi independen hanya bersifat normatif dan menganggap bahwa pelayanan yang diberikan hanya untuk memenuhi kewajiban perpajakannya, bukan untuk mengedukasi wajib pajak.

Idealnya, kepatuhan wajib pajak dalam melaksanakan kewajiban pajak akan meningkat apabila terdapat pelayanan resmi dari petugas otoritas pajak di Indonesia. Pelayanan yang baik dapat memberikan rasa puas bagi wajib pajak. Namun, berdasarkan hasil pengujian dalam penelitian ini, wajib pajak dokter lebih baik menghindari pelayanan dari petugas pajak ketika akan memenuhi kewajiban perpajakannya. Sosialisasi perpajakan sudah cukup membuat pemahaman wajib pajak dengan baik akan kewajiban perpajakannya. Selain itu, wajib pajak menganggap bahwa pelayanan yang diberikan oleh petugas pajak cenderung memaksa bahwa wajib pajak harus memenuhi kewajiban perpajakan, bukan atas dasar keinginan dari diri sendiri wajib pajak untuk memenuhi kewajiban perpajakannya tersebut.

Identifikasi lainnya, petugas pajak mungkin kurang baik merespons wajib pajak ketika mendapatkan permasalahan yang dialami. Terdapat stigma bahwa saat wajib pajak membutuhkan penjelasan secara langsung atau via telepon orang pajak susah dihubungi. Kondisi ini mengakibatkan wajib pajak cenderung menghindari pelayanan yang diberikan otoritas perpajakan. Selain profesi dokter memiliki tingkat pendidikan yang cukup tinggi dan mudah untuk memahami perpajakan melalui sosialisasi, dokter cenderung memilih bertindak praktis dalam memenuhi kewajiban perpajakannya. Apabila wajib pajak dokter sudah memahami perpajakan dengan baik, mereka tidak menggunakan pelayanan yang diberikan otoritas perpajakan dalam membantu penyelesaian kewajiban perpajakannya. Wajib pajak dokter menganggap bahwa penggunaan pelayanan yang diberikan hanya akan digunakan apabila mereka menemukan kendala terkait dengan kewajiban perpajakannya.

\section{Pengaruh Moderasi Kualitas Pelayanan terhadap Pengaruh Sanksi Pajak Terhadap Kepatuhan Pajak}

Hasil pengujian menunjukkan bahwa kualitas pelayanan dapat memperkuat pengaruh positif sanksi pajak terhadap kepatuhan wajib pajak. Hasil pengujian ini sejalan dengan Firnanda (2018). Wajib pajak merasa bahwa petugas pajak dapat memberikan pelayanan yang baik dalam rangka untuk memenuhi kewajiban perpajakannya. Pelayanan yang diberikan oleh pegawai otoritas pajak dibangun melalui profesionalitas, kecekatan dan keramahan. Apabila kondisi tersebut dapat terwujud, wajib pajak akan percaya bahwa 
pemerintah dan otoritas pajak sudah memberikan pelayanan yang baik dan membuat wajib pajak memilih untuk memenuhi kewajiban pajaknya dengan patuh dan benar (Samudra et al., 2020).

Sanksi yang diberikan kepada wajib pajak apabila tidak memenuhi kewajiban perpajakannya dapat didorong melalui pelayanan yang baik. Pelayanan yang diberikan oleh pegawai otoritas pajak lebih cenderung untuk memicu kepatuhan wajib pajak dengan adanya sanksi di kemudian hari. Berdasarkan hasil penelitian ini menunjukkan bahwa pelayanan digunakan ketika wajib pajak menemukan adanya masalah perpajakannya. Untuk menghindari sanksi di kemudian hari, wajib pajak akan berkonsultasi dengan pegawai otoritas pajak. Penelitian ini juga membuktikan bahwa petugas otoritas pajak dapat berperan baik ketika wajib pajak menemukan adanya masalah perpajakannya seperti keterlambatan pembayaran pajak atau perhitungan pajaknya. Profesi dokter sebagai wajib pajak orang pribadi menghindari adanya sanksi pajak di kemudian hari yang dapat merugikan aktivitasnya sebagai profesional yang bekerja secara independen.

\section{KESIMPULAN DAN SARAN}

Sosialisasi perpajakan yang diberikan oleh otoritas perpajakan di Indonesia dapat mendorong kepatuhan wajib pajak orang pribadi khususnya dokter dengan penghasilan independen. Profesi dokter menginginkan adanya kontribusi penghasilan mereka dalam rangka pembangunan negara. Selain itu, adanya sanksi perpajakan yang diberikan kepada otoritas perpajakan dapat meningkatkan kepatuhan wajib pajak. Profesi dokter yang memiliki pekerjaan independen cenderung mematuhi pajak dibandingkan menemukan adanya permasalahan perpajakan di masa mendatang. Penelitian ini juga menemukan bahwa pelayanan yang diberikan oleh petugas otoritas pajak dianggap membantu wajib pajak apabila wajib pajak menemukan adanya masalah perpajakannya. Adanya sanksi yang ditimbulkan apabila wajib pajak dianggap tidak mematuhi perpajakan akan merugikan wajib pajak profesi dokter terkait dengan aktivitas yang dijalankan. Namun, apabila wajib pajak profesi dokter tidak mengalami kendala dalam pemenuhan kewajiban perpajakannya, maka wajib pajak tersebut tidak menggunakan pelayanan yang disediakan oleh otoritas perpajakan. Profesi dokter memiliki pemahaman yang baik terkait dengan perpajakan yang diberikan dalam kegiatan sosialisasi pajak.

Survei kuesioner kepada responden penelitian ini dilakukan cukup singkat yaitu selama 10 hari sejak tanggal 16-25 Maret 2021. Selain itu, survei kepada responden dengan profesi dokter hanya dilakukan dengan wilayah kerja di Jabodetabek. Oleh karena itu, jumlah kuesioner yang digunakan dalam penelitian ini relatif sedikit. Penelitian selanjutnya dapat dilakukan dalam rentang waktu yang lebih lama, sehingga dapat menghasilkan jumlah kuesioner yang lebih banyak untuk mendapatkan hasil penelitian yang lebih baik. Penelitian selanjutnya juga dapat menggunakan responden dokter yang memiliki profesi di wilayah kerja di luar dari Jabodebatek untuk 
untuk membandingkan hasil pengujiannya dengan hasil penelitian ini.

Hasil penelitian ini dapat digunakan sebagai masukan bagi otoritas pajak di Indonesia untuk melakukan perbaikan sehubungan dengan kegiatan sosialisasi dan pelayanan pajak yang telah dilakukan sehubungan dengan meningkatkan kepatuhan wajib pajak, khususnya wajib pajak dokter. Sosialisasi pajak sebaiknya dilakukan secara berkala dan menyeluruh ke segala jenis profesi wajib pajak, dan dilakukan oleh petugas pelayanan pajak dengan kemampuan komunikasi yang baik serta pengalaman yang memadai untuk dapat menjawab berbagai pertanyaan yang timbul dari peserta sosialisasi. Selain itu, pelayanan yang dilakukan bukan hanya untuk wajib pajak yang terindikasi adanya permasalahan kewajiban perpajakannya saja, namun untuk semua jenis pelayanan. Otoritas Perpajakan di Indonesia juga perlu melakukan sosialisasi dalam hal pelayanan yang diberikan di kantor-kantor pelayanan sehingga pelayanan tersebut dapat digunakan oleh semua wajib pajak.

\section{DAFTAR PUSTAKA}

Afdalia, N., Pontoh, G. T., Kartini (2014). Theory of planned behavior and readiness for change dalam memprediksi niat implementasi peraturan pemerintah nomor 71 tahun 2010. JAAI, 18(2), 110-123.

Ajzen, I. (2010). Constructing a theory of planned behavior questionnaire. Biofeedback and Selfregulation. https:// doi.org/10.1016/0749-5978(91)90020-T

Andreoni, J., Erard, B., \& Feinstein, J. (1998). Tax compliance. Journal of economic literature, 36(2), 818-860.
Arham, A., \& Firmansyah, A. (2021). The role of behavioral theory in the research of msmes tax compliance In Indonesia. Riset, 3(1), 417-432.

Azyus, D. I., Syahbandir, M., \& Rahayu, S. W. (2017). Implementasi kebijakan pengampunan pajak kaitannya dengan kepatuhan wajib pajak di Aceh. Syiah Kuala Law Journal, 1(1), 17-39.

Dewi, N. K. A. P., \& Jati, I. K. (2018). Pengaruh Sosialisasi, Kualitas Pelayanan, Sanksi dan Biaya Kepatuhan Pada Tingkat Kepatuhan Wajib Pajak Kendaraan Bermotor. E-Jurnal Akuntansi, 25(1), 1-30. https://doi.org/10.24843/ eja.2018.v25.i01.p01

Dharma, M. T., \& Ariyanto, S. (2014). Analisis faktor-faktor yang memengaruhi tingkat kepatuhan wajib pajak orang pribadi di lingkungan Kantor Pelayanan Pajak Pratama, Tigaraksa. Binus Business Review, 5(2), 497-509.

Eriksen, K., \& Fallan, L. (1996). Tax knowledge and attitudes towards taxation; A report on a quasi-experiment. Journal of Economic Psychology, 17(3), 387-402.

Firmansyah, A. (2020). Kajian yuridis atas praktek transfer pricing oleh korporasi. Indramayu: Adab.

Firnanda, S. (2017). Pengaruh Motivasi Dan Sanksi Terhadap Kepatuhan Wajib Pajak Dengan Pemahaman Dan Pelayanan Sebagai Variabel Moderasi. Jurnal Akuntansi AKUNESA, 6(1), 1-24.

Fitriani, F. F. (2021). https:// ekonomi.bisnis.com/ $\mathrm{read} / 20201202 / 259 / 1325382 /$ ini-strategipemerintah-kejar-penerimaan-pajak-2021bakal-efektif.\%0A

Hair, J. F., Black, W. C., Babin, B. J., \& Anderson, R. E. (2013). Multivariate data analysis. London, UK: Pearson New International Edition. 
Hazmi, M. Z., Suhendro, \& Dewi, R. R. (2020). Pengaruh pemahaman wajib pajak, kualitas pelayanan dan sanksi perpajakan terhadap kepatuhan wajib pajak pada KPP Pratama Surakarta. Jurnal Akuntansi Universitas Jember, 18(1), 28-40.

Imam, Y. (2021). https://nasional.kontan.co.id/ news/defisit-anggaran-sepanjang-tahun2020-mencapai-rp-9563triliun\#: :text=Defisit anggaran sepanjang tahun 2020 mencapai Rp 956\%2C3 triliun,$\mathrm{Rabu} \% 2 \mathrm{C}$ 06 Januari\&text=ILUSTRASI.\&text=Kemente rian Keuangan (Kemenkeu) mencatat d

Indraini, A. (2021). Woro Woro! Situs Lapor SPT Pajak Error. DetikFinance. https:// finance.detik.com/berita-ekonomi-bisnis/d5435486/woro-woro-situs-lapor-spt-pajakerror/2

Kan, M. P. H., \& Fabrigar, L. R. (2017). Theory of Planned Behavior. Encyclopedia of Personality and Individual Differences, 18.

Mahaputri, N. N. T., \& (2021). Noviari, N. (2016). Pengaruh pemahaman peraturan perpajakan, kesadaran wajib pajak dan akuntabilitas pelayanan publik terhadap kepatuhan wajib pajak. E-Jurnal Akuntansi Universitas Udayana, 17(32), 2321-2351.

Mahdani, T. M., \& Ismatullah, I. (2021). Pengaruh sanksi administrasi dan kualitas pelayanan terhadap kepatuhan wajib pajak dalam membayar pajak kendaraan bermotor. JAE: Jurnal Akuntansi Dan Ekonomi, 6(1), 16-25

Murphy, K. (2008). Enforcing Tax Compliance: To Punish or Persuade? Economic Analysis and Policy, 38(1), 113-135.

Nifanngeljau, J., \& Sularsih, H. (2020). Analisis faktor-faktor yang mempengaruhi tingkat kepatuhan wajib pajak orang pribadi pada pelaku usaha mikro kecil menengah (UMKM) di Kelurahan Tlogomas Kota Malang. Jurnal Akuntansi Trisakti,7(2), 265-286.
Nurisdiyanto, W. E. (2019). https:// www.pajak.go.id/id/artikel/betapakrusialnya-pajak-dalam-portal-kehidupanberbangsa-dan-bernegara diakses tanggal 6 Mei 2021.

Oladipupo, A.O., \& Obazee, U. (2016). Tax knowledge, penalties and tax compliance in small and medium scale enterprises in Nigeria. iBusiness, 8, 1-9.

Ortega, D., \& Sanguinetti, P. (2013). Deterrence and reciprocity effects on tax compliance: experimental evidence from Venezuela. CAF Working paper.

Palil, M. R. (2013). The perception of tax payers on tax knowledge and tax education with level of tax compliance: a study the influences of religiosity. ASEAN Journal of Economics, Management and Accounting, 1(1), 118-129.

Pangesti, D. M., \& Yushita, A. N. (2019). Pengaruh kesadaran membayar pajak, persepsi atas efektivitas sistem perpajakan, dan pemahaman peraturan pemerintah Nomor 23 tahun 2018 terhadap kemauan membayar pajak (Pada UMKM sektor perdagangan di Kabupaten Klaten). Nominal: Barometer Riset Akuntansi dan Manajemen, 8(2), 166-178.

Pebrina, R., \& Hidayatulloh, A. (2020). Pengaruh penerapan E-SPT, pemahaman peraturan perpajakan, sanksi perpajakan, dan kualitas pelayanan terhadap kepatuhan wajib pajak. Jurnal Ilmiah Ekonomi dan Bisnis, 17(1), 1-8.

Perdana, E. S., \& Dwirandra, A. A. N. B. Pengaruh kesadaran wajib pajak, pengetahuan perpajakan, dan sanksi perpajakan pada kepatuhan wajib pajak UMKM. E-Jurnal Akuntansi, 30(6), 1458 -1469 .

Pradana, R. F., \& Firmansyah, A. (2020). The role of prevention efforts in association between interactional fairness and taxpayer compliances intentions. International Journal of Scientific \& Technology Research, 9(2), 3176-3186. 
Pratama, R. A., \& Mulyani, E. (2019). Pengaruh kualitas pelayanan petugas pajak, sanksi perpajakan, dan biaya kepatuhan pajak terhadap kepatuhan wajib pajak UMKM Di Kota Padang. Jurnal Eksplorasi Akuntansi, l(3), 1293-1306.

Putra, I. P. F. D., \& Firmansyah, A. (2018). The effect of tax knowledge, reward, and enforcement strategies on smes tax compliance behavior. International Journal of Business And Management Study, 5(2), 13-20.

Putra, A. F. (2020). Kepatuhan wajib pajak UMKM: pengetahuan pajak, sanksi pajak, dan modernisasi sistem. JRAP (Jurnal Riset Akuntansi dan Perpajakan), 7(01), 1-12.

Putri, N. E., \& Nurhasanah, N. (2019). Sosialisasi pajak, tingkat pendidikan dan sanksi pajak terkait dengan kepatuhan wajib pajak UKM. Jurnal STEI Ekonomi, 28(02), 213-232.

Rogers-Glabush, J. (2009). IBFD International tax glossary. IBFD.

Rusmayani, N. M. L., \& Supadmi, N. L. (2017). Pengaruh sosialisasi, pengetahuan, sanksi dan kualitas pelayanan pada kepatuhan wajib pajak kendaraan bermotor. E-Jurnal Akuntansi Universitas Udayana 20(1), 173 -201 .

Samudra, T. B., Maslichah, \& Sudaryanti, D. (2020). Pengaruh sikap, norma subjektif, dan kontrol keperilakuan yang dipersepsikan terhadap kepatuhan wajib pajak orang pribadi di Kota Batu. E-Jra, 09 (01), 127-143.

Savitri, E., \& Musfialdy. (2016). The effect of taxpayer awareness, tax socialization, tax penalties, compliance cost at taxpayer compliance with service quality as mediating variable. Procedia - Social and Behavioral Sciences, 219, 682-687. https:// doi.org/10.1016/j.sbspro.2016.05.051

Sesarista, N. (2020). Pengaruh Pengetahuan Perpajakan, Kualitas Pelayanan Pajak, Sosialisasi, dan Sanksi Perpajakan
Terhadap Kepatuhan Wajib Pajak Dalam Membayar PBB-P2 di Kota Tangerang Selatan. Tax \& Accounting Review, 21(1), $1-9$.

Setiyawan, E., Sugiarti, S., \& Sutanto, E. M. (2020). Pengaruh sosialisasi, pemahaman dan kesadaran, terhadap kemauan membayar pajak terkait Peraturan Pemerintah Nomor 23 tahun 2018 (Studi kasus pada pelaku UMKM di Kota Surakarta). Riset Manajemen dan Akuntansi, 11(2), 1-14.

Suardana, K. P., \& Gayatri, G. Pengaruh sosialisasi perpajakan, pengetahuan perpajakan dan perhitungan tarif pajak pada kepatuhan pajak mahasiswa pelaku UMKM. E-Jurnal Akuntansi, 30(9), 2311 -2322 .

Sukesi, S., \& Yunaidah, I. (2020). The effect of tax socialization, superior service, and service quality on taxpayers' satisfaction and compliance. Journal of Economics, Business, \& Accountancy Ventura, 22(3), 347-359.

Sujarweni, V. W. (2015). SPSS Untuk Penelitian. Yogyakarta, Indonesia: Pustaka Baru Press.

Syafira, E. Z. A., \& Nasution, R. (2021). Pengaruh sanksi perpajakan dan kualitas pelayanan terhadap kepatuhan wajib pajak. EL MUHASABA: Jurnal Akuntansi (e-Journal), 12(1), 79-91.

Syaputra, R. (2019). Pengaruh persepsi wajib pajak atas penerapan Peraturan Pemerintah Nomor 23 tahun 2018 dan pemahaman perpajakan terhadap kepatuhan wajib pajak usaha mikro, kecil, dan menengah dengan sosialisasi perpajakan sebagai variabel moderasi. Jurnal Magister Akuntansi Trisakti, 6(2), 121-144.

Syambudi, I. (2020). https://tirto.id/nasibtenaga-medis-saat-pandemi-dibayangicorona-dan-kena-phk-fKkL 
Wardani, D. K., \& Kartikasari, F. (2020). Pengaruh sosialisasi PP 23/2018 terhadap kepatuhan wajib pajak UMKM dengan pemahaman wajib pajak sebagai variabel intervening. Jurnal Penelitian Ekonomi dan Akuntansi (JPENSI), 5(1), 1-16.

Yasa, M. A. P. (2017). Perilaku Kepatuhan Perpajakan dalam Perspektif Teori Perilaku Terencana. Seminar Nasional Riset Inovatif, 3, 247-252.

Zelmiyanti, R., \& Suwardi, E. (2019). Dampak moderasi moral perpajakan pada hubungan perceived probability of audit dan sanksi terhadap perilaku kepatuhan pajak usaha mikro, kecil dan menengah (UMKM). Journal of Applied Accounting and Taxation, 4(1), 69-78.

Zulma, G. W. M. (2020). Pengaruh pengetahuan wajib pajak, administrasi pajak, tarif pajak dan sanksi perpajakan terhadap kepatuhan pajak pada pelaku usaha UMKM di Indonesia. Ekonomis: Journal of Economics and Business, 4(2), 288-294.

https://www.pajak.go.id/id/kinerja-page diakses tanggal 8 Maret 2021

https://nasional.kontan.co.id/news/defisitanggaran-sepanjang-tahun-2020-mencapairp-9563-triliun diakses tanggal 6 Mei 2021

https://www.pajak.go.id/id/siaran-pers/lampauitarget-pelaporan-spt-menteri-keuanganapresiasi-kantor-ini 